\title{
ディーゼル噴霧の液滴分裂の噴射量依存性
}

\author{
斎藤 学*1, 駒田 佳介*2, 坂口 大作*3，植木 弘信*3
}

\section{Dependence of droplet breakup of diesel spray on injection amount}

\author{
Manabu SAITO $^{* 1}$, Keisuke KOMADA ${ }^{* 2}$, Daisaku SAKAGUCHI ${ }^{* 3}$ and Hironobu UEKI*3 \\ ${ }^{* 1}$ IRS, 19-8 Shinjuku-cho, Higashimatsuyama-shi, Saitama 355-0032, Japan \\ ${ }^{* 2}$ Fukuoka Institute of Technology, 3-30-1 Wajiro-higashi, Higashi-ku, Fukuoka 811-0295, Japan \\ ${ }^{* 3}$ Nagasaki University, 1-14 Bunkyo-machi, Nagasaki 852-8521, Japan
}

Received: 2 July 2020; Revised: 23 August 2020; Accepted: 4 September 2020

\begin{abstract}
A laser 2-focus velocimeter (L2F) was used for the measurements of the velocity and size of droplets in diesel fuel sprays. The L2F had a micro-scale probe which consists of two foci. The focal diameter was about $3 \mu \mathrm{m}$, and the distance between two foci was $24 \mu \mathrm{m}$. The fuel was stored once in a common rail and was injected intermittently to the atmosphere. The diameter of the nozzle orifice was $0.15 \mathrm{~mm}$, and the number of holes was 6 . The injection pressure was set at $60 \mathrm{MPa}$, and the amounts of fuel were set at 1.1 and $7.0 \mathrm{mg}$ per injection. It was confirmed that the size of droplets near the nozzle under a smaller amount of injection was smaller than the one under a larger amount of injection. The droplet size decrease rate in the direction of spray injection was found to be larger at the spray upstream region compared to at the spray downstream region. There was a positive correlation between the droplet size decrease rate under a smaller amount of injection and the one under a larger amount of injection. The droplet breakup of diesel sprays was less dependent on the injection amount.
\end{abstract}

Keywords : Heat engine, Compression ignition engine, Fuel injection/Fuel spray, Laser measurement

\section{1. まえがき}

ディーゼル機関に更なる高効率化と同時に有害排出物質の低減が求められており，それらの達成のために燃焼 制御が重要である．燃料を直接シリンダ筒内に噴射するディーゼル機関において，然料の噴霧特性が燃焼におよ ぼす影響は大きく，然料を複数回に分けて噴射する多段噴射を適用することで熱損失が低減し，図示熱効率が向 上することが報告されている(佐田他，2015). また，各噴射の噴射量割合が NOx 排出量に影響を及ぼすことが報 告されている(Mobasheri et al., 2012). 燃料噴射条件の変更に基づく燃焼制御を推進するには噴霧の基本特性の把 握が不可欠であり，特に噴霧内部の情報の取得が求められている．噴霧液滴を計測する手法として位相ドップラ 一流速計(Lacoste et al., 2003)や粒子画像流速計(Payri et al., 2016)等が用いられてきた．しかし噴霧内部では液滴の 数密度が高いことから個々の液滴の計測は容易でなく，噴射期間中の液滴分裂領域における計測例はほとんどな い.

レーザー2 焦点流速計(L2F; Laser 2-Focus velocimeter)はその計測体積が微小であることから，高数密度場におけ る液滴の速度とサイズの計測に活用されている．著者らは，開発の初期に L2F による粒径計測の精度を顕微鏡画 像から求められたガラスビーズの粒径との比較により検証した(Ueki et al., 1994). これまでに，L2Fによるディー ゼル噴霧内の局所的な液滴質量流量の評価法を提案し，その積分によって求められた噴射量と実噴射量がほぼ一 致することを確認した(駒田他, 2011). また，多段噴射におけるパイロットあるいはポスト噴射を念頭に行われた 少量噴射の試験では，噴射量の減少とともに噴霧液滴のサイズが噴孔近傍で減少することを明らかにした (Komada et al., 2019).

No.20-00243 [DOI:10.1299/transjsme.20-00243], J-STAGE Advance Publication date : 14 September, 2020

*1 (株) アイ・アール・エス（三355-0032 埼玉県東松山市新宿町 19-8）

*2 正員, 福岡工業大学 工学部（广811-0295 福岡県福岡市東区和白東3-30-1）

*3 正員, 長崎大学 工学研究科（广852-8521 長崎県長崎市文教町 1-14）

E-mail of corresponding author: ueki@nagasaki-u.ac.jp 
本研究では燃料の噴射量を変化させ，噴孔近傍の複数断面において L2F を用いて噴霧内部の液滴を計測し，燃 料噴射の向きの液滴サイズの減少率を評価することによって液滴分裂の噴射量依存性を調查した.

\section{2. 実験装置および実験方法}

\section{$2 \cdot 1$ レーザー2 焦点流速計}

図 1 は $\mathrm{L} 2 \mathrm{~F}$ の計測体積を示す．焦点直径 $F$ は $3 \mu \mathrm{m}$ ，焦点長さ $L$ は $20 \mu \mathrm{m}$ ，焦点間距離 $S$ は $24 \mu \mathrm{m}$ である. 図 2 は 2 焦点の構造と液滴の飛行時間・散乱時間との関係を示寸. 液滴が 2 つの焦点を通過する際の飛行時間 $t_{1}$, 上 流焦点における散乱時間 $t_{2}$ および下流焦点における散乱時間 $t_{3}$ を周波数 $480 \mathrm{MHz}$ のクロックで計数する. 液滴速 度 $V_{p}$ を， 2 焦点間距離 $S$ を飛行時間 $t_{1}$ で割ることにより求める.

$$
V_{p}=\frac{S}{t_{1}}
$$

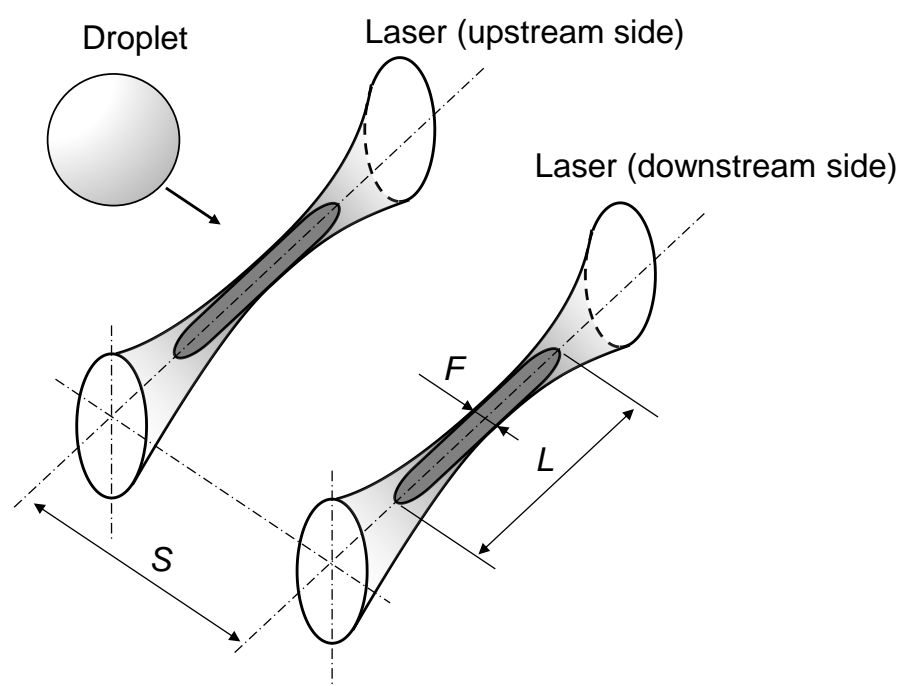

Fig. 1 Light probe of L2F. The two foci have the same structure, each with a diameter of $3 \mu \mathrm{m}$ and a length of $20 \mu \mathrm{m}$. And the distance between two foci is $24 \mu \mathrm{m}$.

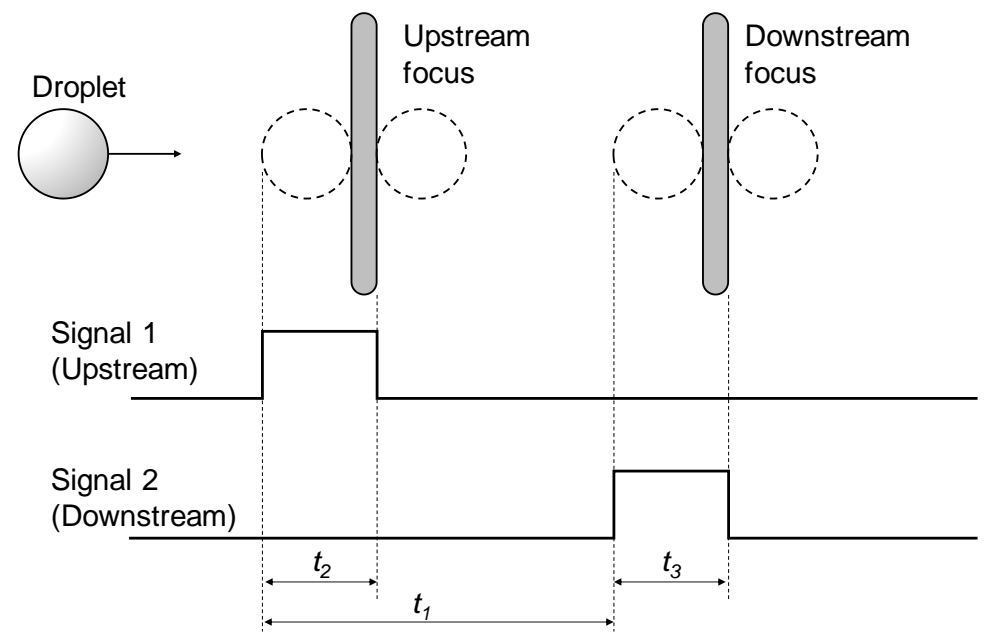

Fig. 2 Time-of-flight and time-of-scattering of L2F. Two kinds of timeare measured by FPGA to determine the velocity and size of droplet. 
液滴サイズ $D_{p}$ と焦点サイズ $F$ の和が散乱時間と液滴速度の積に対応すること，また散乱時間として $t_{2}$ と $t_{3}$ の平 均值を用いることにより，液滴サイズを次式より求める.

$$
D_{p}=V_{p} \cdot \frac{t_{2}+t_{3}}{2}-F
$$

液滴の分裂を定量的に評価するため, $\mathrm{L} 2 \mathrm{~F}$ の計測データに基づいて, 液滴のサイズ減少 $d D_{p}$ をその移動距離 $d z$ で除して $d D_{p} / d z$ を算出した. 次に, チェーンルールに基づいて, 液滴の速度 $V_{p}$ を掛けて, 次式により単位時間当 たりの液滴サイズ減少率 $d D_{p} / d t$ を求めた.

$$
\frac{d D_{p}}{d t}=\frac{d D_{p}}{d z} \frac{d z}{d t}=V_{p} \frac{d D_{p}}{d z}
$$

\section{$2 \cdot 2$ 計測システム}

図 3(a)にL2F を用いた噴霧計測システムを示す.燃料を高圧ポンプにより加圧し, コモンレールに蓄圧した後, インジェクタから噴射した．噴孔出口を座標軸の原点として計測点を表示することとし，噴射の向きに $z$ 軸， $\mathrm{L} 2 \mathrm{~F}$ のレーザー光射出の向きに $y$ 軸, $y-z$ 平面に垂直に $x$ 軸を取った. $\mathrm{L} 2 \mathrm{~F}$ は最大出力 $100 \mathrm{~mW}$, 波長 $830 \mathrm{~nm}$ の半 導体レーザーを光源とし, 収束レンズとして焦点距離が $8 \mathrm{~mm}$ の非球面レンズを採用した. 光学系の全長は約 $350 \mathrm{~mm}$ である. 2 つの焦点における液滴からの後方散乱光を別個の APD (Avalanche Photodiode)に導いて電気信号 に変換した. FPGA (Field Programmable Gate Array) で構成したデジタルカウンタを用いて，一対の電気信号パル スから飛行時間および散乱時間を計数した.インジェクタソレノイドに噴射開始信号を印加してから L $2 \mathrm{~F}$ のデー 夕取得までの経過時間を $6 \mathrm{MHz}$ のクロックで計数した．図3(b)は燃料噴射ノズル先端の構造を示す．燃料はシー ト，サックを経由して，噴孔から外部へ噴射される。シート部の流路面積が噴孔総面積より狭い小弁開度の状態 はシート絞りと呼ばれ，シートからサックへの流路の急拡大による乱れの発生(Salvador et al., 2013), あるいはサ ックから噴孔への大きな曲がりによるキャビテーションの発生(Guo et al., 2018)が報告されている.

\section{$2 \cdot 3$ 噴射条件および計測条件}

噴射条件および計測条件を表 1 に示寸．インジェクタの噴孔径は $0.15 \mathrm{~mm}$ であり，噴孔数は 6 である. 噴射圧 力を $60 \mathrm{MPa}$ ，噴射当たりの燃料質量を 1.1 および $7.0 \mathrm{mg} / \mathrm{inj}$.に設定し，大気圧場に周期 $3 \mathrm{~Hz}$ で噴射した． 6 噴孔の

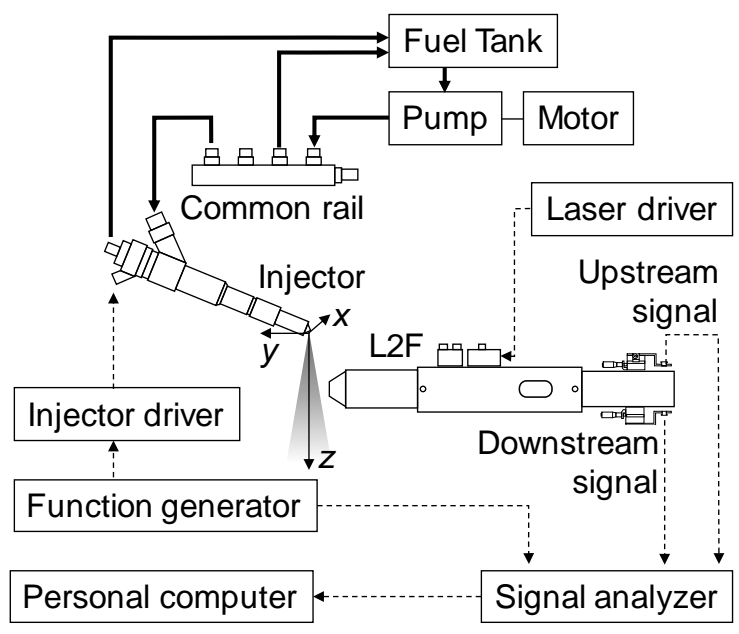

(a) Fuel spray measurement system

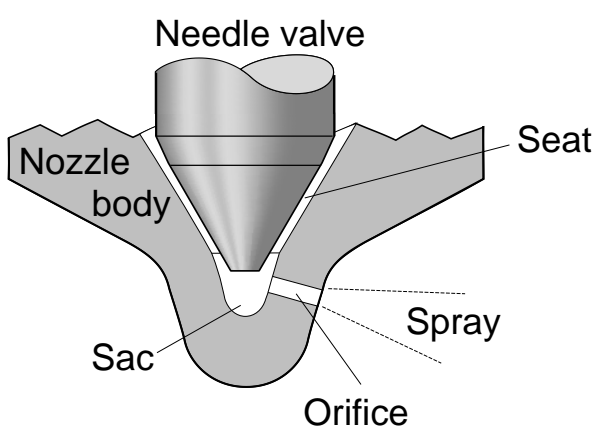

(b) Schematic of injector nozzle

Fig. 3 Fuel spray measurement system and injector nozzle. This system is consisted of a fuel pump, injector, $\mathrm{L} 2 \mathrm{~F}$ and signal processor. 
内の 1 つの噴孔から噴射された噴霧を L2F で計測し，他の噴孔からの噴霧を細い流路に導いて回収した.

噴孔出口から 4，6，8 および $10 \mathrm{~mm}$ 下流の断面において L2F による計測を行った. 計測点の配置を図 4 に示 す. 噴霧中心が $x=0 \mathrm{~mm}$ であり,$z=4 \mathrm{~mm}$ の断面における計測点を $x=0, \pm 0.1, \pm 0.2, \pm 0.3$ およ゙゙ $\pm 0.4 \mathrm{~mm}$ の 9 点 とした. $z>4 \mathrm{~mm}$ の各断面における計測点について, $x / z$ を, $z=4 \mathrm{~mm}$ の断面における 9 点の $x / z$ と同じ值，すなお ち $x / z=0, \pm 0.025, \pm 0.05, \pm 0.075$ および \pm 0.1 とした。噴孔近傍では噴霧が噴孔を頂点としてほぼ円錐状に広がる ことから，計測点を噴孔から放射状に配置している．各計測点における取得データ数は 20000 点である.

\section{3. 結果および考察}

図 5(a)は $z=4 \mathrm{~mm}$ の断面における時間空 $0.1 \mathrm{~ms}$ 毎の算術平均液滴速度の時間変化を示す. 噴射量 $Q$ は $7.0 \mathrm{mg} / \mathrm{inj}$. である．横軸は噴射開始信号印加からの経過時間を示す，緑丸，黄丸，青丸，赤丸および黒丸はそれぞれ $x=0$, 0.1，0.2，0.3 および $0.4 \mathrm{~mm}$ の場合を示す．また図中のエラーバーは $95 \%$ 信頼区間を示す．噴射初期の $T=0.5 \sim$ $0.6 \mathrm{~ms}$, および噴射終期の $T=2.1 \sim 2.2 \mathrm{~ms}$ において, $x$ による液滴速度の変化は小さく, それぞれの時期において 速度の空間分布はほぼ一様である. $x=0 \mathrm{~mm}$ の場合, 液滴速度は $T=0.5 \sim 0.9 \mathrm{~ms}$ において増加し, $T=0.9 \sim 1.8 \mathrm{~ms}$

Table 1 Experimental condition. Diesel fuel sprays were injected from a 6-hole injector at a pressure of $60 \mathrm{MPa}$ and were measured on 4 planes.

\begin{tabular}{|c|c|}
\hline \multicolumn{2}{|c|}{ Injector specifications } \\
\hline Number of hole [-] & 6 \\
\hline Hole diameter [mm] & 0.15 \\
\hline \multicolumn{2}{|c|}{ Test conditions } \\
\hline Injection frequency [Hz] & 3 \\
\hline Rail pressure [MPa] & 60 \\
\hline $\begin{array}{c}\text { Injection quantity } \\
\text { per injection [mg / inj.] }\end{array}$ & 1.1 and 7.0 \\
\hline Ambient pressure [MPa] & 0.1 \\
\hline \multicolumn{2}{|c|}{ Measurement positions } \\
\hline $\mathrm{z}$ [mm] & $0, \pm 0.1, \pm 0.2, \pm 0.3, \pm 0.4$ \\
\hline 4 & $0, \pm 0.15, \pm 0.3, \pm 0.45, \pm 0.6$ \\
\hline 6 & $0, \pm 0.2, \pm 0.4, \pm 0.6, \pm 0.8$ \\
\hline 8 & $0, \pm 0.25, \pm 0.5, \pm 0.75, \pm 1.0$ \\
\hline 10 &
\end{tabular}

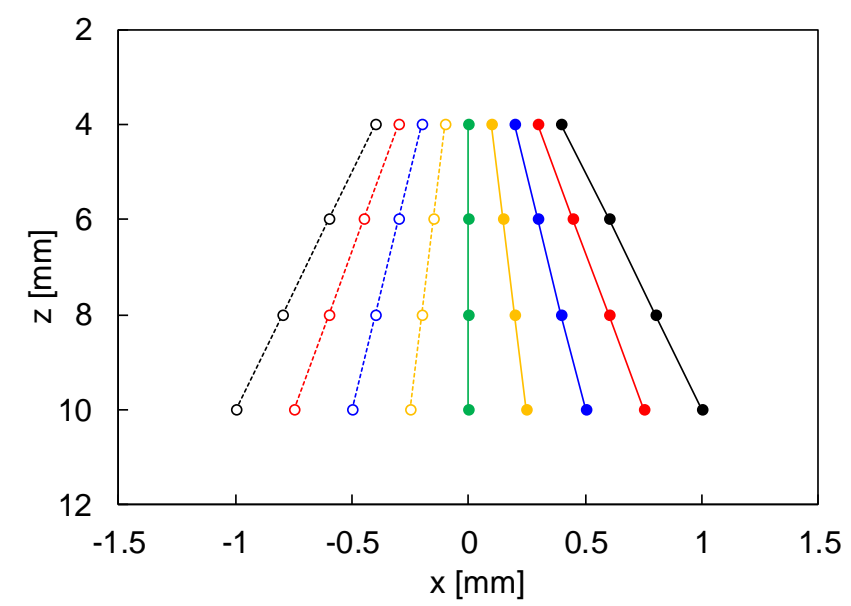

Fig. 4 Geometric arrangement of measurement positions. The normalized radius $x / z$ were set at $0, \pm 0.025, \pm 0.05, \pm 0.075$ and \pm 0.1 in each measurement plane. 
の間で変化が小さく, その後, 減少した. サック内圧が噴射期間の前半で増加し, 後半で減少することが報告さ れている（Wang et al., 2003）。本研究においても開弁時のサック内圧力の増加，ならびに閉弁時のサック内圧力の 減少がそれぞれの時期の液滴速度の増加ならびに減少となって現れたと推察される. $x=0.1,0.2,0.3$ および $0.4 \mathrm{~mm}$ においては， $x$ の増加とともに，液滴速度が増加あるいは減少する期間が短縮され，速度変化が小さい期間が相 対的に延びている．噴霧周辺部は静止した周囲空気の影響を受けるため噴霧中心に比べて噴霧周辺部の液滴の速 度は低い值にとどまり，サック内圧力の増加および減少の影響が小さいと考えられる．図 5(b)は算術平均液滴サ イズの時間変化を示す. 噴射初期の $T=0.5 \sim 0.6 \mathrm{~ms}$ ，および噴射終期の $T=2.1 \sim 2.2 \mathrm{~ms}$ において， $x$ の増加ととも に液滴サイズは減少しており, 分裂によって生じた小サイズ液滴が噴霧周辺部に現れたものと考えられる.また, この小サイズ液滴は噴霧中心の速度と同程度の速度で飛行しているものと理解される. $x=0 \mathrm{~mm}$ の場合, 液滴业 イズは $T=0.5 \sim 0.6 \mathrm{~ms}$ において減少している，ノズル内部において，針弁開度が小さいとき，狭いシート部から サックへの流路の急拡大によって流れが乱され，噴霧角が広がることが報告されている(Moon et al., 2019). この 乱れのために液滴の分裂が促進され, 噴霧全域に及んだものと考えられる. その後, 液滴サイズは $T=0.6 \sim 1.0 \mathrm{~ms}$ において増加し, $T=1.0 \sim 1.7 \mathrm{~ms}$ の間で変化が小さい. 弁開とともにシート部流れに起因するサック内の乱れが減 少し，一方，噴孔内の速度増加による乱れ増加の影響は相対的に小さいものと考えられる. $T=1.7 \sim 2.1 \mathrm{~ms}$ の間で 液滴サイズは減少し, $T=2.1 \sim 2.2 \mathrm{~ms}$ の間で増加した. 弁開度減少に伴う乱れの増加によって液滴の分裂が促進さ れ, 続く弁閉直前には低速で乱れが小さいため分裂が進まず大きな液滴となって現れたものと考えられる. $x=0.1$, 0.2 および $0.3 \mathrm{~mm}$ においても，速度が増加する期間におけるサイズの増加，および速度が減少する期間における サイズの減少が観察された. $x=0.4 \mathrm{~mm}$ の噴霧周辺部においては, 他の $x$ に比べて液滴サイズが小さくかつその 時間的変化も小さい. 分裂によって生じた小サイズ液滴が噴射の全期間にわたって噴霧周辺部に現れるものと考 えられる。

図 6(a) は噴孔下流 $4 \mathrm{~mm}$ の噴霧中心において噴射量の変化に伴う液滴速度の変化を示寸．黒丸および赤丸はそ れぞれ $Q=1.1$ および $7.0 \mathrm{mg} / \mathrm{inj}$.の場合を示す. $Q=7.0 \mathrm{mg} / \mathrm{inj}$.の場合の液滴速度は図 6(a)の $x=0 \mathrm{~mm}$ のプロットの

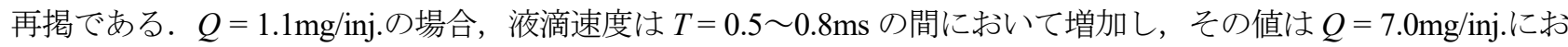
ける同時刻の液滴速度とほぼ同じ值であった. $Q=1.1 \mathrm{mg} / \mathrm{inj}$.の場合に，その最高速度が $Q=7.0 \mathrm{mg} / \mathrm{inj}$.の場合に比 ベて低いことから, シート絞りの状態, すなわち噴孔総面積に比べてシート部流路面積が狭い状態と考えられる. 図 6(b)は液滴サイズの時間変化を示寸. $Q=1.1 \mathrm{mg} / \mathrm{inj}$.の場合， $T=0.5 \sim 0.8 \mathrm{~ms}$ の間において液滴サイズは $Q=7.0 \mathrm{mg} / \mathrm{inj}$.における同時刻の液滴サイズとほぼ同じ值を示した。噴射期間の短縮によって噴射量を減少させた 本研究においては, $T=0.8 \mathrm{~ms}$ まで, $Q=1.1 \mathrm{mg} / \mathrm{inj}$. の針弁挙動が $Q=7.0 \mathrm{mg} / \mathrm{inj}$.の場合とほぼ同じと考えられる. $Q=1.1 \mathrm{mg} / \mathrm{inj}$.の場合に，その最大液滴サイズが $Q=7.0 \mathrm{mg} / \mathrm{inj}$.の場合に比べて小さい. 小弁開度時にサック内の燃

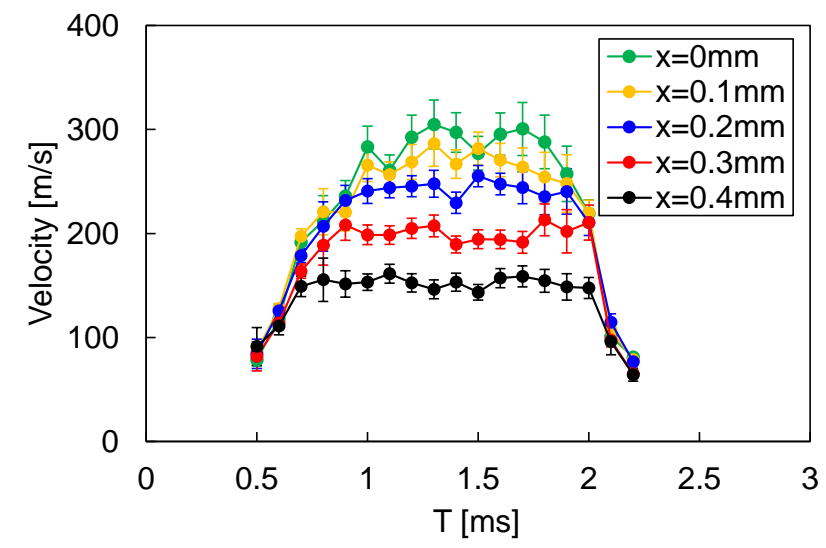

(a) Velocity

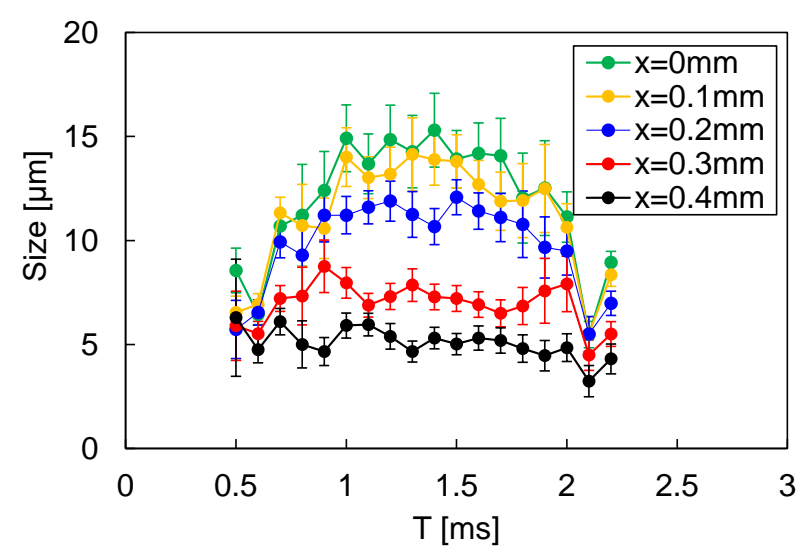

(b) Size

Fig. 5 Time variations of velocity and size of droplets, $z=4 \mathrm{~mm}, Q=7.0 \mathrm{mg} / \mathrm{inj}$. The increase and decrease of droplet velocity with time was clearly observed at the spray center. The decrease of droplet size at the early stage of injection was observed over the spray section. 
料流動の乱れが増加すること(Salvador et al., 2013)，ならびにサック内の渦強度が増加すること(Moon et al., 2019) が報告されている. $Q=1.1 \mathrm{mg} / \mathrm{inj}$.の場合, 噴射期間が短いため弁開度が小さく, 小弁開度に起因したノズル内部の 燃料流動の乱れの増加が噴射期間にわたって生じ，液滴分裂が活発であったと推察される. また， $Q=7.0 \mathrm{mg} / \mathrm{inj}$. においても液滴の速度およびサイズが最大かつ定常になる時期まで続いているものと推定される.

噴霧液滴の速度およびサイズは，時間的・空間的に変化する．噴射量変更に伴う噴霧特性の変化を， $z=4 \mathrm{~mm} の$ 噴霧中心の液滴の速度およびサイズが時間的にほぼ最大となる噴射中期のデータに基づいて評価することとした。 すなわち， $Q=1.1$ および $7.0 \mathrm{mg} / \mathrm{inj}$. において，それぞれの噴射中期は $T=0.7 \sim 0.8 \mathrm{~ms}$ および $T=1.1 \sim 1.7 \mathrm{~ms}$ とな る. 図 7(a)は $Q=7.0 \mathrm{mg} / \mathrm{inj}$.の場合の噴射中期における液滴速度の空間分布である. 緑丸，黄丸，青丸および赤丸 はそれぞれ $z=4,6,8$ および $10 \mathrm{~mm}$ を示す.いずれの断面においても噴霧周辺部の計測点に比べて噴霧中心の液 滴速度は高い。噴霧下流に向かって噴霧中心近傍における液滴速度は明確に減少し, また噴霧幅の広がりととも に噴霧周辺部の液滴速度も減少している. 図 7(b)は液滴サイズの空間分布を示す．いずれの断面においても噴霧 外側の計測点に比心噴霧中心の液滴サイズは大きい，噴霧上流に比べて噴霧下流では，噴霧中心近傍の液滴サイ ズは小さく，また，噴霧周辺部において液滴サイズが小さい領域が増している. 図 8 は $Q=7.0 \mathrm{mg} / \mathrm{inj}$.の場合の

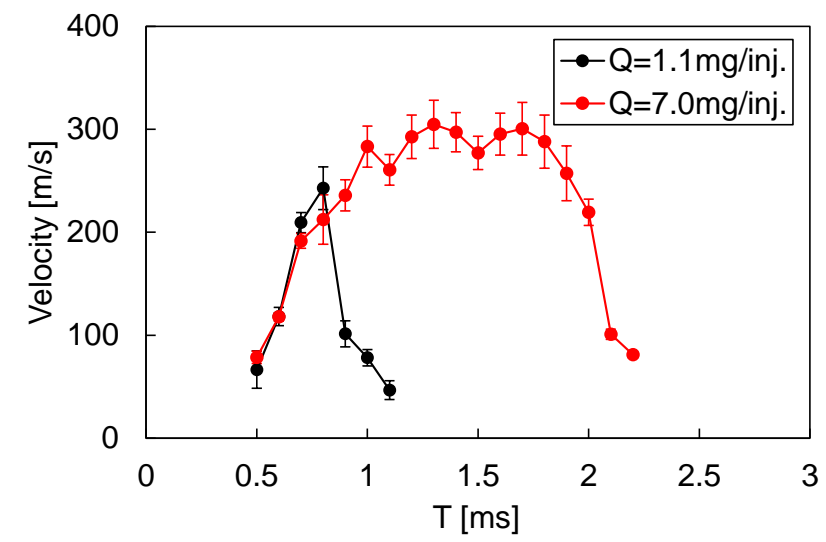

(a) Velocity

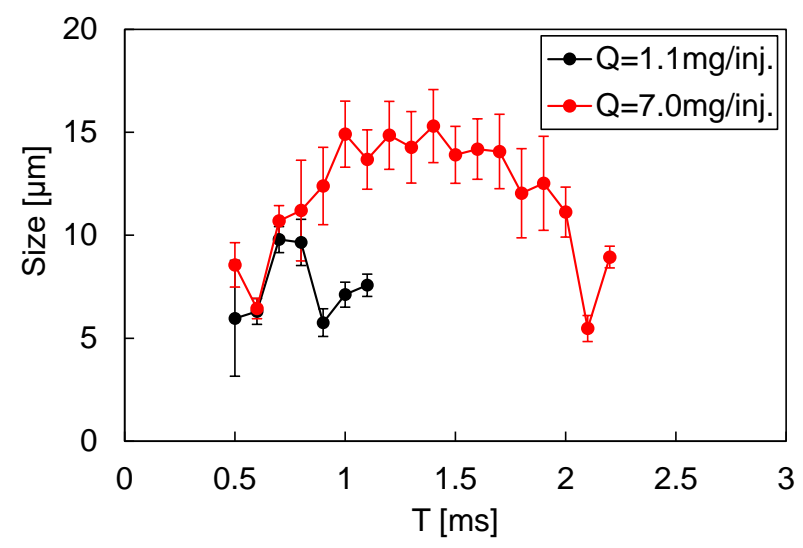

(b) Size

Fig. 6 Time variations of velocity and size of droplets at spray center, $z=4 \mathrm{~mm}$. The highest velocity and largest size of droplets on $Q=1.1 \mathrm{mg} / \mathrm{inj}$. were lower and smaller than these on $Q=7.0 \mathrm{mg} / \mathrm{inj}$.

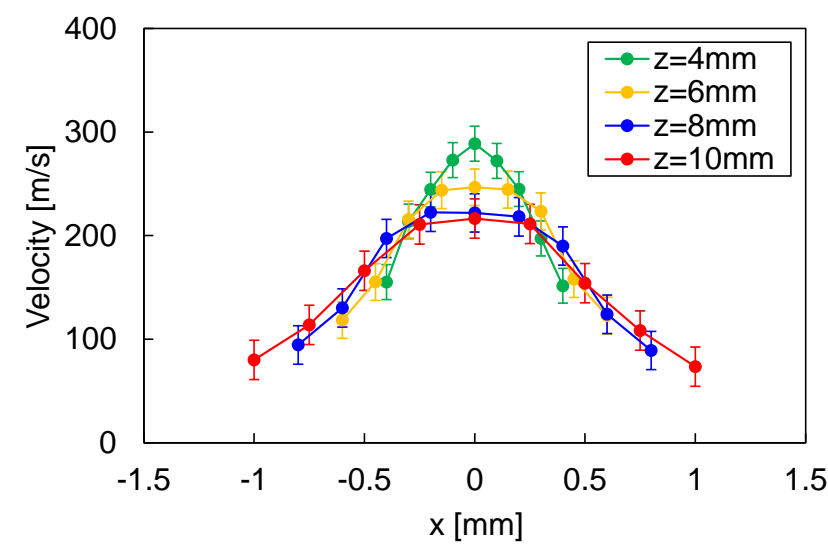

(a) Velocity

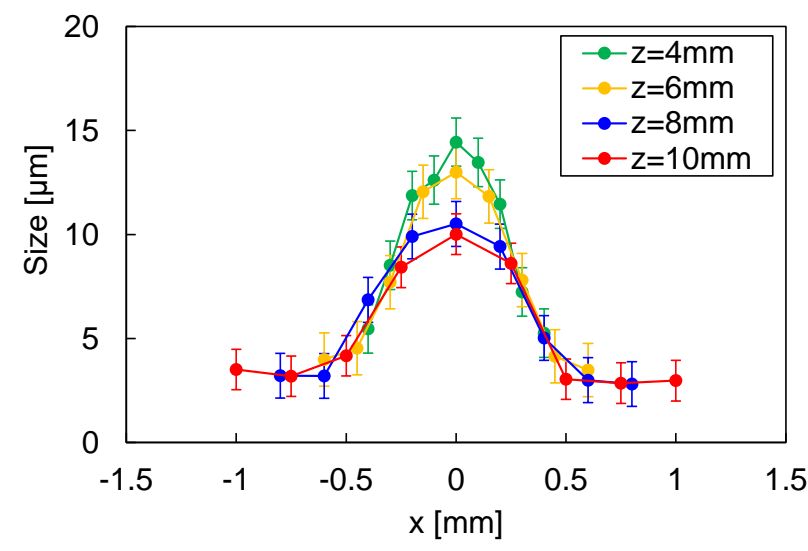

(b) Size

Fig. 7 Spatial distributions of velocity and size at middle period of injection on $\mathrm{Q}=7.0 \mathrm{mg} / \mathrm{inj}$. The velocity of droplets at the spray center was higher than the one at the spray periphery, and the size of droplets at the spray center was larger than the one at the spray periphery. 
$x / z=0.1$ における噴射中期の液滴サイズの確率密度分布を示寸. ほとんどの液滴は, $z=4 \mathrm{~mm}$ では $20 \mu \mathrm{m}$ 以下, $z$ $=6 \mathrm{~mm}$ では $15 \mu \mathrm{m}$ 以下, $z=8$ および $10 \mathrm{~mm}$ では $10 \mu \mathrm{m}$ 以下であった. Melling らは, 2.6 $\mu \mathrm{m}$ のシリコンオイルの粒 子が $1 \mathrm{kHz}$ の周波数をもつ流速変動に, 誤差 $1 \%$ 以内で追従することを報告している(Melling and Whitelaw, 1975). 分裂がほぼ完了したと考えられる $3 \mu \mathrm{m}$ 以下の液滴の確率の空間分布を図 9 に示寸. 噴霧上流に比べて噴霧下流で は, 噴霧周辺部において $3 \mu \mathrm{m}$ 以下の液滴の確率が高い領域が増している.これらより, 小サイズ液滴は噴霧の下 流向きの飛行に加えて噴霧の外周側へ飛行すると判断される.

図 10(a)は噴射中期における液滴の平均速度の軸方向変化である. 緑丸，黄丸，青丸，赤丸および黒丸はそれぞ れ $x / z=0,0.025,0.05,0.075$ および 0.1 を示し，また，実線は $Q=1.1 \mathrm{mg} / \mathrm{inj}$.の場合を，破線は $Q=7.0 \mathrm{mg} / \mathrm{inj}$.の場 合を示寸．両噴射量のいずれの $x / z$ においても液滴の速度は噴霧下流に向かい減少した. $z=4 \mathrm{~mm}$ における噴霧の 中心およびその近傍を含む $x / z<0.075$ で，各 $x / z$ の $Q=7.0 \mathrm{mg} / \mathrm{inj}$.の液滴速度に比べて同じ $x / z$ の $Q=1.1 \mathrm{mg} / \mathrm{inj}$ の 值は格段に低い．また，このことは $z>4 \mathrm{~mm}$ の断面においても同様である. 図 10(b)は平均液滴サイズの軸方向変 化を示す. 噴霧の周辺部かつ下流側計測点の $\mathrm{x} / \mathrm{z}=0.1, \mathrm{z}=8 \sim 10 \mathrm{~mm}$ を除く, いずれの噴射量, および半径位置に おいても液滴サイズは噴射の向きに減少した。噴孔近傍において液滴サイズが減少する傾向は位相ドップラー流 速計(Lee and Park, 2002)やX 線(Kastengren et al., 2017)を用いた場合においても報告されている. 本研究において 計測対象とした噴霧においても下流に向かって液滴の分裂が進行したものと判断される. 各 $z$ 断面の $x / z<0.075$ において, 各 $x / z$ の $Q=7.0 \mathrm{mg} / \mathrm{inj}$.の液滴サイズに比べて同じ $x / z$ の $Q=1.1 \mathrm{mg} / \mathrm{inj}$.における值は顕著に小さい.

図 11 は噴射中期における液滴サイズ減少率を無次元半径位置 $x / z$ に対する空間分布として示す. 緑丸, 青丸お よび赤丸はそれぞれ $z=4 \sim 6 \mathrm{~mm}, z=6 \sim 8 \mathrm{~mm}$ ，および $z=8 \sim 10 \mathrm{~mm}$ の場合であり，破線および実線はそれぞれ

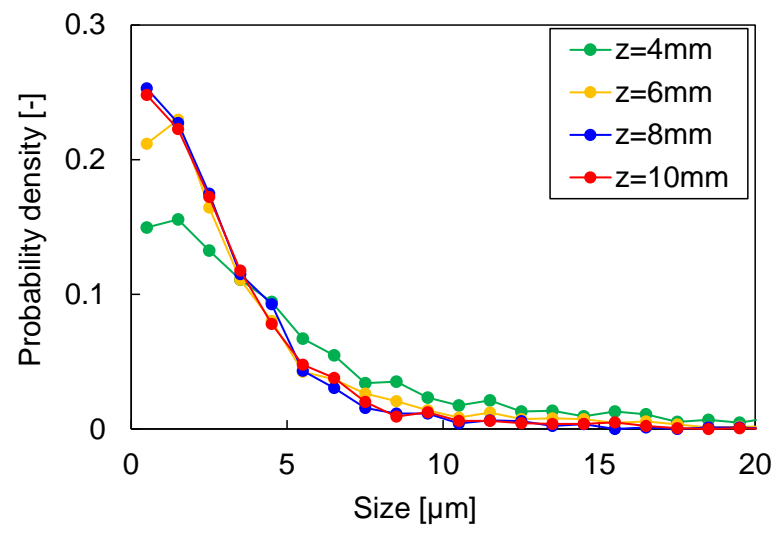

Fig. 8 Probability densities of size of droplets at middle period of injection on $\mathrm{Q}=7.0 \mathrm{mg} / \mathrm{inj} . ; x / z=0.1$. The size of most droplets was $20 \mu \mathrm{m}$ or less at $\mathrm{z}=4 \mathrm{~mm}$, was $15 \mu \mathrm{m}$ or less at $\mathrm{z}=6 \mathrm{~mm}$, was $10 \mu \mathrm{m}$ or less at $\mathrm{z}=8 \mathrm{~mm}$.

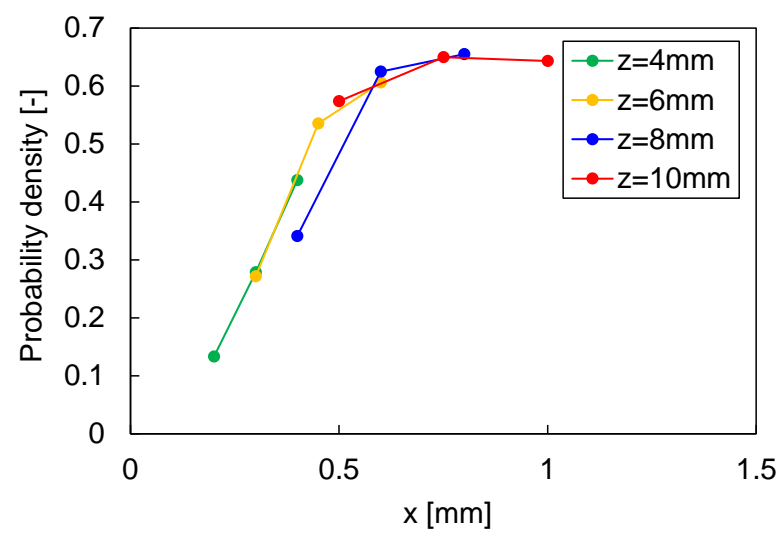

Fig. 9 Spatial distributions of probability of droplets smaller than $3 \mu \mathrm{m}$ on $Q=7.0 \mathrm{mg} / \mathrm{inj}$. The probabilities were high at the spray periphery on the downstream regions. 
$Q=1.1$ および $7.0 \mathrm{mg} / \mathrm{inj}$. の場合である. $x / z$ が \pm 0.025 より外側において,$z=8 \sim 10 \mathrm{~mm}$ に比べて $z=4 \sim 6 \mathrm{~mm}$ におけ る液滴サイズ減少率が大きいことから噴霧上流で液滴の分裂が活発と考えられる. $x / z$ が \pm 0.05 より外側において, $z=8 \sim 10 \mathrm{~mm}$ における液滴サイズ減少率がほぼゼロとなっていることから，この領域では液滴の分裂が終了した

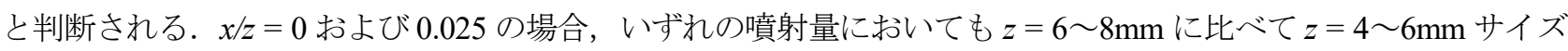
減少率が小さい，前述したように，分裂後の小さな液滴は噴霧の外周部へ向かって飛行するため，噴霧の中央部 の $z=6 \mathrm{~mm}$ において平均液滴サイズがやや過大に評価され， $z=4 \sim 6 \mathrm{~mm}$ で液滴サイズ減少率が小さくなったも のと推定される. $Q=1.1$ および 7.0mg/inj.の液滴サイズ減少率の空間分布はいずれの $z$ 位置においても非一様で あるにもかかわらず，それらの形状はほぼ同様であった。

図 12 は同じ $z$ 位置および $x / z$ において,$Q=1.1$ および $7.0 \mathrm{mg} / \mathrm{inj}$.の液滴サイズ減少率の相関を示す. 緑丸，青 丸および赤丸はそれぞれ $z=4 \sim 6 \mathrm{~mm}, z=6 \sim 8 \mathrm{~mm}$ ，および $z=8 \sim 10 \mathrm{~mm}$ における液滴サイズ減少率である. 黒の 実線は両噴射量における液滴サイズ減少率が一致するときの相関線を示し，黒の破線はプロットの標準偏差を示 す.ばらつきがあるものの, $Q=7.0 \mathrm{mg} / \mathrm{inj}$.の液滴サイズ減少率と $Q=1.1 \mathrm{mg} / \mathrm{inj}$. の液滴サイズ減少率には正の相関 があり，相関係数は 0.84 であった。両者はほぼ同レベルであることから液滴サイズ減少率におよぼす噴射量の影 響は大きくないものと考えられる.

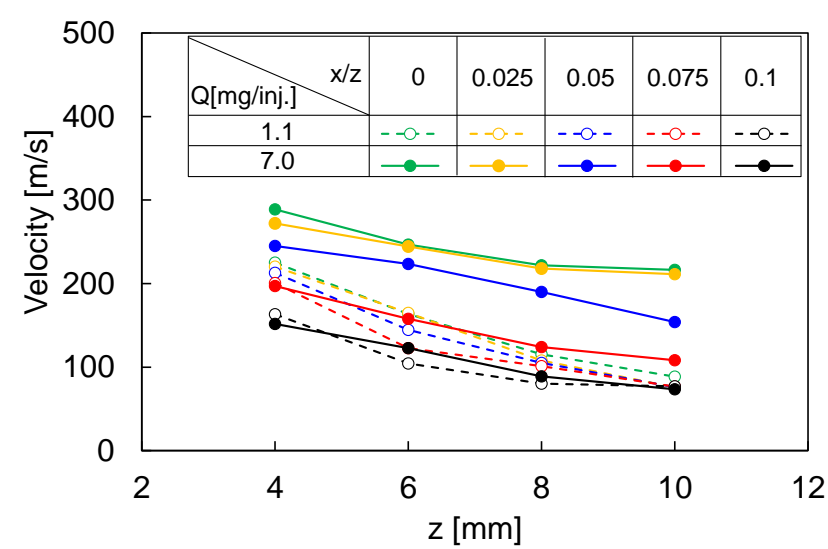

(a) Velocity

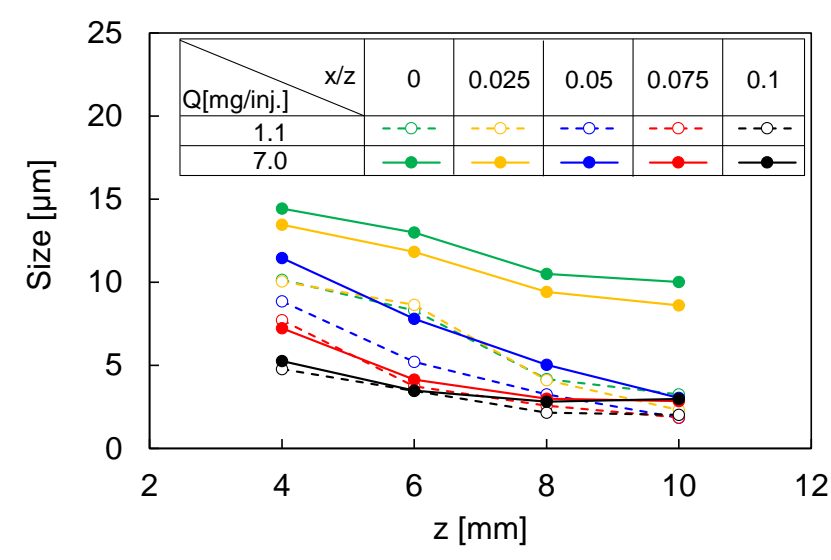

(b) Size

Fig. 10 Axial distributions of velocity and size at middle period of injection. The velocity and size of droplets decreased downstream of the spray.

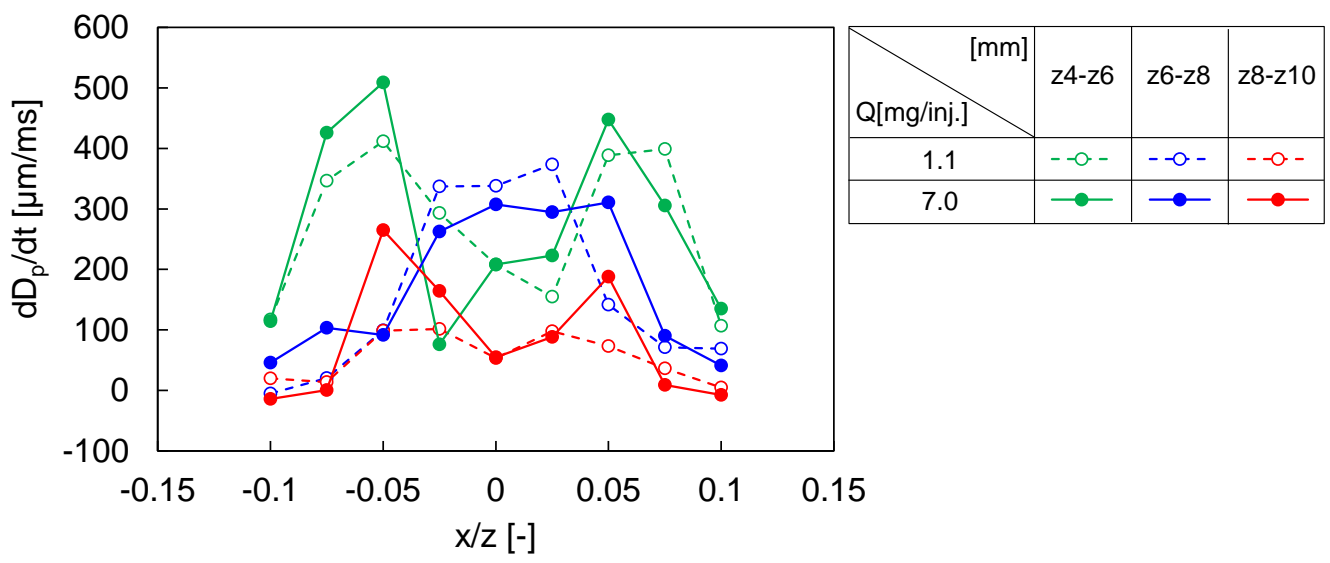

Fig. 11 Spatial distributions of droplet size decrease rate per unit time at middle period. The droplet size decrease rate on $Q=7.0 \mathrm{mg} / \mathrm{inj}$. was nearly the same as that on $Q=1.1 \mathrm{mg} / \mathrm{inj}$. 


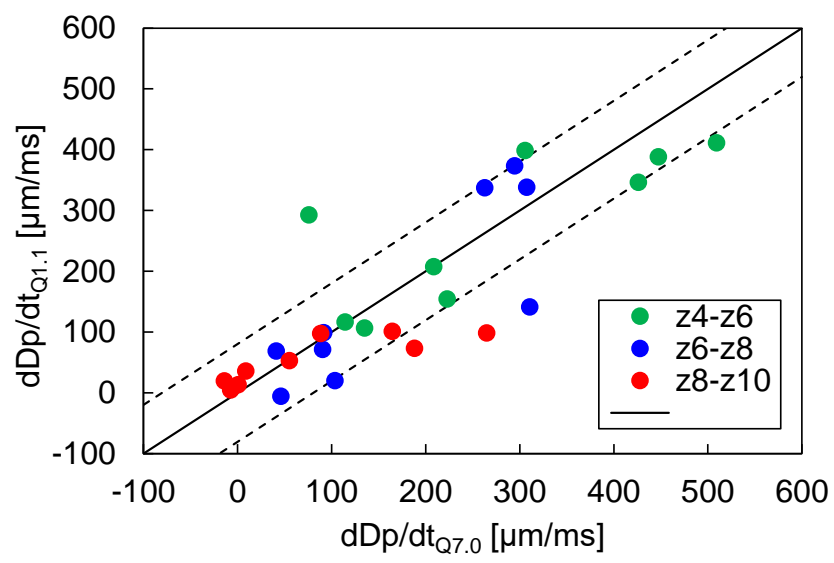

Fig.12 Correlation of droplet size decrease rate between $Q=1.1$ and $7.0 \mathrm{mg} / \mathrm{inj}$. at middle period. There was a positive correlation between the droplet size decrease rate on $Q=7.0 \mathrm{mg} / \mathrm{inj}$. and the one on $Q=1.1 \mathrm{mg} / \mathrm{inj}$.

\section{4. まとめ}

噴射圧が 60MPa, 噴射量が 1.1 および 7.0mg/inj.の条件でコモンレールインジェクタを用いてディーゼル燃料 を大気中に噴射した。燃料噴霧の液滴の速度およびサイズを噴孔下流 $4 ， 6 ， 8$ および $10 \mathrm{~mm}$ の断面において $\mathrm{L} 2 \mathrm{~F}$ を用いて評価し，以下の知見を得た。

（1）噴霧中心近傍において，噴射量が多い場合に比べて噴射量が少ない場合の液滴サイズは小さい.

(2) いずれの噴射量においても噴霧上流に比べて噴霧下流の液滴サイズは小さく, 液滴は下流に向かって分 裂が進行したものと判断される.

(3) 噴孔下流の噴霧外縁において，いずれの噴射量においても液滴サイズ減少率がゼロに近いことから液滴 の分裂が終了したものと判断される.

（4）噴射量の多い場合の液滴サイズ減少率と少量噴射の場合の液滴サイズ減少率との間に正の相関があり， 液滴サイズ減少率におよぼす噴射量の影響は小さい.

\section{文献}

Guo, G., He, Z., Jin, Y., Chen, Z., Duan, X. and Leng, X., Visualization investigations of flow regimes in different sizes diesel injector nozzles and effects on spray, Atomization and Sprays, Vol. 28, Issue 6(2018), pp. 547-563.

Kastengren, A., Ilavsky, J., Viera, J. P., Payri, R. and Powell, C. F., Measurements of droplet size in shear-driven atomization using ultra-small angle x-ray scattering, International Journal of Multiphase Flow, Vol. 92(2017), pp.131-139.

Komada, K., Saito, M. and Ueki, H., Effect of injection amount on diesel spray characteristics of multi-hole nozzle, SAE Technical Paper 2019-01-2284(2019), pp. 1-6.

駒田佳介, 坂口大作, 植木弘信, 石田正弘, L2F を用いたディーゼル燃料噴霧高数密度領域の液滴質量分布の評 価, 日本機械学会論文集 B 編, Vol.77, No.774(2011), pp. 274-281.

Lacoste, J., Crua, C., Heikal, M., Kennaird, D. and Gold, M., PDA characterisation of dense diesel sprays using a common-rail injection system, SAE Paper, No.2003-01-3085(2003), pp. 2074-2085.

Lee, C. S. and Park, S. W., An experimental and numerical study on fuel atomization characteristics of high-pressure diesel injection sprays, Fuel, Vol. 81, Issue 18(2002), pp. 2417-2423.

Melling, A. and Whitelaw, J. H., Optical and flow aspects of particles, The Accuracy of Flow Measurements of Laser Doppler Methods(1975), pp.382-402.

Mobasheri, R., Peng, Z. and Mirsalim, M. S., Analysis the effect of advanced injection strategies on engine performance and pollutant emissions in a heavy duty DI-diesel engine by CFD modeling, Journal of Heat and Fluid Flow, Vol. 33(2012), pp. 59-69. 
Moon, S., Huang, W. and Wang, J., First observation and characterization of vortex flow in steel micronozzles for high-pressure diesel injection, Journal of experimental thermal and fluid science, Vol. 105(2019), pp. 342-348.

Payri, R., Viera, J. P., Wang, H. and Malbec, L. M., Velocity field analysis of the high density, high pressure diesel spray, Journal of Multiphase Flow, Vol. 80(2016), pp. 69-78.

Salvador, F. J., Martínez-López, J., Caballer, M. and Alfonso, C. D., Study of the influence of the needle lift on the internal flow and cavitation phenomenon in diesel injector nozzles by CFD using RANS methods, Journal of Energy Conversion and Management, Vol. 66 (2013), pp.246-256.

佐田翼, 伊藤聡一郎, 喜久里陽, 草鹿仁, 大聖泰弘, 山口恭平, 鈴木央一, 石井素, 小型ディーゼルエンジンにおけ る多段噴射による熱損失低減と熱効率向上に関する研究，自動車技術会論文集, Vol. 46, No. 4(2015), pp. 755761.

Ueki, H., Ishida, M. and Sakaguchi, D., Simultaneous measurement of particle size and velocity by laser 2-focus particle analyzer, Proceedings of ICLASS-94(1994), pp.483-490.

Wang, T. C., Han, J. S., Xie, X. B., Lai, M. C., Henein, N. A., Schwarz, E. and Bryzik, W., Parametric characterization of highpressure diesel fuel injection systems, Journal of engine gas turbines power, Vol. 125(2003), pp. 412-426.

\section{References}

Guo, G., He, Z., Jin, Y., Chen, Z., Duan, X. and Leng, X., Visualization investigations of flow regimes in different sizes diesel injector nozzles and effects on spray, Atomization and Sprays, Vol. 28, Issue 6(2018), pp. 547-563.

Kastengren, A., Ilavsky, J., Viera, J. P., Payri, R. and Powell, C. F., Measurements of droplet size in shear-driven atomization using ultra-small angle x-ray scattering, International Journal of Multiphase Flow, Vol. 92(2017), pp.131-139.

Komada, K., Saito, M. and Ueki, H., Effect of injection amount on diesel spray characteristics of multi-hole nozzle, SAE Technical Paper 2019-01-2284(2019), pp. 1-6.

Komada, K., Sakaguchi, D., Ueki, H. and Ishida, M., Estimation of mass distribution of diesel fuel spray in high-number density region by L2F, Transactions of the Japan Society of Mechanical Engineers, Series B, Vol.77, No.774(2011), pp.274-281 (in Japanese).

Lacoste, J., Crua, C., Heikal, M., Kennaird, D. and Gold, M., PDA characterisation of dense diesel sprays using a common-rail injection system, SAE Paper, No.2003-01-3085(2003), pp. 2074-2085.

Lee, C. S. and Park, S. W., An experimental and numerical study on fuel atomization characteristics of high-pressure diesel injection sprays, Fuel, Vol. 81, Issue 18(2002), pp. 2417-2423.

Melling, A. and Whitelaw, J. H., Optical and flow aspects of particles, The Accuracy of Flow Measurements of Laser Doppler Methods(1975), pp.382-402.

Mobasheri, R., Peng, Z. and Mirsalim, M. S., Analysis the effect of advanced injection strategies on engine performance and pollutant emissions in a heavy duty DI-diesel engine by CFD modeling, Journal of Heat and Fluid Flow, Vol. 33 (2012), pp. 59-69.

Moon, S., Huang, W. and Wang, J., First observation and characterization of vortex flow in steel micronozzles for high-pressure diesel injection, Journal of experimental thermal and fluid science, Vol. 105(2019), pp. 342-348.

Payri, R., Viera, J. P., Wang, H. and Malbec, L. M., Velocity field analysis of the high density, high pressure diesel spray, Journal of Multiphase Flow, Vol. 80(2016), pp. 69-78.

Salvador, F. J., Martínez-López, J., Caballer, M. and Alfonso, C. D., Study of the influence of the needle lift on the internal flow and cavitation phenomenon in diesel injector nozzles by CFD using RANS methods, Journal of Energy Conversion and Management, Vol. 66(2013), pp.246-256.

Sata, T., Ito, S., Kikusato, A., Kusaka, J., Daisho, Y., Yamaguchi, K., Suzuki, H. and Ishii, H., A Study on heat loss reduction and thermal efficiency improvement in a light-duty diesel engine by means of multiple fuel injection, Transactions of Society of Automotive Engineers of Japan, Vol. 46, No. 4(2015), pp. 755-761(in Japanese).

Ueki, H., Ishida, M. and Sakaguchi, D., Simultaneous measurement of particle size and velocity by laser 2-focus particle analyzer, Proceedings of ICLASS-94(1994), pp.483-490.

Wang, T. C., Han, J. S., Xie, X. B., Lai, M. C., Henein, N. A., Schwarz, E. and Bryzik, W., Parametric characterization of highpressure diesel fuel injection systems, Journal of engine gas turbines power, Vol. 125(2003), pp. 412-426. 